\title{
IN MEMORIAM \\ MILDRED ZAPATA SERRANO \\ 1952 - 2018
}

\author{
Lorelei Albanese ${ }^{1}$ and Wanda I. Lugo ${ }^{2}$
}

J. Agric. Univ. P.R. 102 (1-2):133-134 (2018)

Dr. Mildred Zapata Serrano, an active researcher until her untimely death, was Professor of Plant Pathology in the Department of Agroenvironmental Sciences at the University of Puerto Rico, Mayagüez Campus (UPR-M). For more than 40 years, her research was centered on the study of bacterial diseases that affect the production of major crops and ornamental plants in Puerto Rico. Research topics included the classification of endophytes and common bacteria using microbiological, biochemical and some molecular techniques, identification of disease resistance in economically important plant species and biological control of the coffee bean borer insect using bacteria.

A native Mayagüezana, she received a B.S. in biology (magna cum laude) in 1974 and M.S. degree in crop protection in 1982 from UPR-M. She served as an assistant researcher and instructor in different aspects of phytopathology from 1974 to 1985 . In 1985 she took a leave to complete her doctorate in plant pathology at the University of Nebraska-Lincoln. She worked under the supervision of noted phytopathologist Dr. Anne Vidaver and in 1989, earned her Ph.D. in plant pathology with a specialization in bacterial pathogens. Her doctoral dissertation focused on pathogen-host interactions of the tepary bean with the common bean pathogen Xanthomonas campestris pv. phaseoli.

"Dr. Zapata began work with common beans in the 1970s as a technician in the laboratory of Dr. Nader Vakili at the USDA-ARS Tropical Agricultural Research Station (TARS) in Mayaguez," her colleagues recounted in a tribute in the Bean Improvement Cooperative 2018 annual report ${ }^{3}$. They continued: "She conducted research to improve greenhouse and field screening techniques for evaluating beans for re-

${ }^{1}$ English-language Editor, Agricultural Experiment Station, University of Puerto Rico-Mayagüez Campus.

${ }^{2}$ Editor, Agricultural Experiment Station, University of Puerto Rico-Mayagüez Campus.

${ }^{3}$ Drs. James S. Beaver, Timothy Porch and Consuelo Estevez collaborated in the preparation of the In Memoriam for Dr. Zapata in the 2018 Annual Report of the Bean Improvement Cooperative. 
sistance to common bacterial blight. Dr. Zapata collaborated with Dr. George Freytag, former USDA/ARS Research Geneticist at TARS and Dr. Robert Wilkinson, Professor at Cornell University, in the development of bean lines with common bacterial blight resistance derived from scarlet runner beans ( $P$. coccineus). This led to the release of five bean germplasm lines that have high levels of resistance to common bacterial blight. One of these lines was used as a progenitor of 'Verano', which is currently the most popular white bean in Puerto Rico. Dr. Zapata also collaborated with Dr. Freytag and Dr. Mark Bassett in the development and release of the common bacterial blight interspecific breeding line XR-235-1."

Her colleagues related, "In 2010, Dr. Zapata and collaborators reported that a single dominant gene, Xap-1, that conferred resistance to Xap strain 3353 had been identified. The SCAR SAP6 marker, located on B10, was found to co-segregate with the resistant phenotype. In recent years, Dr. Zapata has participated in the development and release of several breeding lines and cultivars that have enhanced levels of resistance to common bacterial blight."

Among Dr. Zapata's projects funded by grants over the years were: the genetic improvement of beans for yield, pest resistance and food value; the potential effects of Xylella fastidiosa on shade coffee trees, and new and prevalent bacterial strains associated with diseased plantain and bananas and their survival in soil in Puerto Rico.

Dr. Zapata was an active board member of the non-profit 'Programa Cooperativo Regional de Frijol (PROFRIJOL)' and in 1993 became a member of the Executive Committee of PROFRIJOL, comprising representatives from 11 countries in Central America, Mexico and the Caribbean. Dr. Zapata served as acting associate dean of the College of Agricultural Sciences in 1998 and on the Plant Health Council of the Commonwealth Department of Agriculture from 1997 to 2002. She was appointed to the Industrial Biotechnology Program of UPR-M in 2002. She was a member of the American Phytopathological Society since 1990, and she presided the Gamma Sigma Delta Honor Society 19921993.

She trained numerous graduate and undergraduate students. For nearly 15 years she was a member of the Graduate Council of the Ma yagüez Campus, where students knew her to be cordial, efficient, innovative and always willing to help them. In summary, one student wrote: "We are infinitely grateful for your example of sacrifice, love of life, and dedication to Puerto Rican science." 